\title{
ENZYME-ASSISTED EXTRACTION OF CAROTENOIDS FROM BULGARIAN TOMATO PEELS
}

\author{
T. Prokopoa*, M. Nikolova ${ }^{a}$, G. Dobrev ${ }^{\mathrm{b}}$ and D. TANeVA ${ }^{\mathrm{a}}$ \\ ${ }^{a}$ Department of Environmental Engineering, University of Food Technologies, 26 Maritsa Blvd., \\ 4000 Plovdiv. Bulgaria \\ ${ }^{\mathrm{b}}$ Department of Biochemistry, University of Food Technologies, 26 Maritsa Blvd., 4000 Plovdiv. Bulgaria
}

(Received: 13 June 2016; accepted: 4 August 2016)

\begin{abstract}
Enzyme-assisted extraction of carotenoids from tomato peels of the Bulgarian cultivar "Stela", one of the most widely used cultivars by the canning industry, was examined in this study. The carotenoid content in raw tomato peels was established by HPLC analysis. A two-step protocol was followed: the tomato peels were first treated with enzymes and then extracted by the use of acetone as a solvent for $30 \mathrm{~min}$ at $20 \pm 1{ }^{\circ} \mathrm{C}$ and solid/liquid ratio of $1: 30$. The total carotenoid, lycopene, and $\beta$-carotene extraction yields were increased by the use of pectinase, cellulase, endo-xylanase, and proteinase enzymes in comparison with the non-enzyme-treated samples. The increase in the extraction yield was affected by the enzymes used, the enzyme concentration, the pretreatment time and temperature. Maximum total carotenoid (55.15 mg/100 g d.w.), $\beta$-carotene (35.85 mg/100 g d.w.), and lycopene (15.44 mg/100 g d.w.) extraction yields were obtained in peels pretreated with mixed cellulase $\left(100 \mathrm{U} \mathrm{g} \mathrm{g}^{-1}\right)$ and endo-xylanase (400 $\mathrm{U} \mathrm{g}^{-1}$ ) for $4 \mathrm{~h}$ at $50^{\circ} \mathrm{C}$. Carotenoid recovery by mixed cellulolytic and hemi-cellulolytic enzyme pretreatment of tomato peels is a good approach, which can be used for waste utilization.
\end{abstract}

Keywords: tomato, peels, enzyme, extraction, carotenoids, yield

The tomato processing industry generates significant amounts of tomato residues, thereby creating environmental problems. At present, large quantities of tomato skin and outer pericarp tissue are discarded as a waste product from the peeling operation. The amount of waste generated during tomato processing and the supposed health benefits of its components justify the great interest of researchers and manufacturers in extracting carotenoids from tomato wastes (STRATI \& Oreopoulou, 2011).

The amount of lycopene in ordinary industrial tomato varieties depends on their genotype and degree of maturity and ranges from 3 to $10 \mathrm{mg} / 100 \mathrm{~g}$, whereas the $\beta$-carotene level reaches $5 \mathrm{mg} / 100 \mathrm{~g}$ (GonZÁlez et al., 2011; NiKolova et al., 2014). A number of new tomato cultivars with increased lycopene content have been developed recently (HDIDER et al., 2013). The average lycopene content in high-pigment tomato hybrid cultivars is almost double in comparison with ordinary cultivars (LENUCCI et al., 2010). The amount of lycopene in tomato peels ranges from 5 to $100 \mathrm{mg} / 100 \mathrm{~g}$ (ILAHY et al., 2016).

Common organic solvents and solvent mixtures have been applied to carotenoid extraction (Strati \& Oreopoulou, 2011). The optimal conditions for conventional organic solvent extraction of carotenoids from the peels of Bulgarian tomato cultivar "Stela", one of the most widely used cultivars by the canning industry, were established in our previous study (NiKolova et al., 2014).

\footnotetext{
* To whom correspondence should be addressed.

Phone: +359 32603 888; fax: +359 32644 102; e-mail: tsvetko_prokopov@abv.bg
} 
It is well known that lycopene is present as red crystals within the chromoplasts. These crystals are enclosed into newly synthesized membranes originating by introflections of the inner membrane plastid envelope (SiMKIN et al., 2007). Since the primary cell wall of tomato is composed mainly of cellulose, hemicelluloses, and a large amount of pectic polysaccharides, the use of cellulase, xyloglucanase, and pectinase enzymes to hydrolyze and degrade the polysaccharide network could improve the release of carotenoids (LENUCCI et al., 2015). Most of the authors have demonstrated that treatment with cell wall degrading enzymes enhances the solvent penetration and the loss of cell integrity, leading to a remarkable increase in the lycopene extraction yield and reduction of the extraction time and temperature (CHOUdHARI \& AnAnthanarayan, 2007; Zuorro et al., 2011; Cuccolini et al., 2013; RAnveer et al., 2013; ZuORRo et al., 2013, 2014; STRATI et al., 2015). Recently, it was reported that initial enzymatic pretreatment of tomato peels followed by surfactant-assisted extraction resulted in extraction yields ten times as high as those of untreated peels (PAPAionnnou \& Karabelas, 2012). Enzyme pretreatment was efficiently combined with sonication and $\mathrm{SC}-\mathrm{CO}_{2}$ extraction for tomato lycopene recovery (KonwARH et al., 2012; LENUCCI et al., 2015). A thorough knowledge of enzymes, their mode of action, and the conditions for their optimum activity, together with selection of the right types of enzymes, are essential for their efficient usage for extraction purposes (Sowbhagya \& Chita, 2010).

On the basis of the above considerations, we explored the feasibility of using cell wall degrading enzymes as a means of improving carotenoid extraction from tomato peels. This study was designed to investigate the effects of enzyme treatment on the yield of carotenoid extraction from peels of the Bulgarian industrial tomato cultivar "Stela".

\section{Materials and methods}

\subsection{Raw materials}

The tomatoes were grown under open-field conditions at the Maritsa Vegetable Crop Research Institute, Plovdiv district, Bulgaria. Fresh red-ripe tomatoes were blanched at $95{ }^{\circ} \mathrm{C}$ for 2 min, cooled in tap water, and hand peeled. The tomato peels obtained were subsequently airdried at $25 \pm 1{ }^{\circ} \mathrm{C}$, ground in a laboratory mill (Bosch MKM 6003, Germany), and sieved through a $1.0 \mathrm{~mm}$ sieve. The moisture content of the dry ground tomato peels was determined by gravimetric method at $105{ }^{\circ} \mathrm{C}$ and was found to be $4.61 \pm 0.21 \%$. The resultant material was kept in glass jars closed with aluminium foil at $-20{ }^{\circ} \mathrm{C}$ until the start of the experiments.

\subsection{Enzymes and chemicals}

Cellulase from Trichoderma reesei $\left(\mathrm{pH}_{\mathrm{opt}} 5.0,697.68 \mathrm{U} \mathrm{g}^{-1}\right)$, pectinase from Aspergillus niger $\left(\mathrm{pH}_{\mathrm{opt}} 5.0,1569.35 \mathrm{U} \mathrm{g}^{-1}\right)$, endo-xylanase from Aspergillus niger $\left(\mathrm{pH}_{\mathrm{opt}} 5.0,14841.60 \mathrm{U} \mathrm{g}^{-1}\right)$, and proteinase from Bacillus subtilis $\left(\mathrm{pH}_{\mathrm{opt}} 8.0,299.00 \mathrm{U} \mathrm{g} \mathrm{g}^{-1}\right)$ were procured from Biovet Ltd., Peshtera, Bulgaria. HPLC grade acetone and methanol, tetrachloromethane, acetonitrile, and methyl tert-butyl ether (MTBE) of analytical grade were purchased from Sigma, Germany. Standards of lutein, lycopene, and $\beta$-carotene were supplied by Extrasynthese, France. 


\subsection{Solvent extraction of carotenoids}

The extraction of carotenoids was performed in a $250 \mathrm{ml}$ conical glass flask wrapped with aluminium foil. The flask was placed in a temperature-controlled water bath and continuously agitated with a magnetic stirrer (VELP Scientifica, Italy) at 400 r.p.m. A 1.00 g sample was weighed, placed in the extraction flask, and stirred with acetone for $30 \mathrm{~min}$ at $20 \pm 1{ }^{\circ} \mathrm{C}$ and solid/liquid ratio of 1:30. The extract obtained was vacuum filtered through MN640de filter paper. The absorbance was measured using a UV-VIS spectrophotometer (UV-Helios Omega, USA) at 448 and $472 \mathrm{~nm}$ according to MANUELYAN (1991).

\subsection{Enzyme-assisted extraction of carotenoids}

The enzymatic treatment of tomato peels for carotenoid extraction was carried out according to the following procedure. The reaction mixture was prepared using $1.00 \mathrm{~g}$ of dry ground material to which cellulase, pectinase, endo-xylanase, and proteinase enzyme solutions had been added, alone or in combination, prepared by dissolving the commercial enzyme on the basis of the determined specific activity in $0.1 \mathrm{M}$ acetate buffer ( $\mathrm{pH}$ 5.0) for the first three enzymes and in $0.1 \mathrm{M}$ phosphate buffer $(\mathrm{pH}$ 8.0) for proteinase. The reaction mixture was continuously stirred at $20 \pm 1^{\circ} \mathrm{C}$ for $1,2,3,4$, and $5 \mathrm{~h}$. It was filtered through MN640de filter paper and the residues obtained were subjected to solvent extraction following the procedure described above. The influence of different enzyme amounts was examined using different enzyme concentrations for $1 \mathrm{~h}$ pretreatment time.

\subsection{Carotenoid analysis}

For the identification of individual carotenoids, dried tomato peels were analysed using an HPLC system (Waters, Milford, USA) composed of a UV-VIS detector (Waters 2487 Dual $\lambda$ ), a Waters 1525 binary pump, and thermostat (LCO 102). The HPLC system was equipped with a $\mathrm{C}_{18}$ column, $25 \mathrm{~cm} \times 4.6 \mathrm{~mm}, 5 \mu \mathrm{l}$ particle (Supelco Discovery HS). Mobile phases of methanol:acetonitrile at 8:2 ratio and $\mathrm{MTBE}$ were used. The flow rate was maintained at $1 \mathrm{ml} \mathrm{min}{ }^{-1}$, the column temperature at $30^{\circ} \mathrm{C}$, and detection was carried out at $270 \mathrm{~nm}$ and 290 nm.

\subsection{Statistical analysis}

All experiments were run in triplicate. The data were analysed and presented as mean values with standard deviation. Statistical analysis was conducted using SigmaPlot 11.0 software. Statistical techniques, incl. Lavene's test, ANOVA, and Duncan's Multiple Range Test, were applied to determine the significant differences at 95\% confidence $(\mathrm{P}<0.05)$ level.

\section{Results and discussion}

The carotenoid content in tomatoes is influenced by several factors such as agricultural practices, soil, climatic factors, fruit growth, harvesting date, degree of maturity, and postharvest handling (LENUCCI et al., 2010; HDIDER et al., 2013). Our results indicated that the main carotenoids contained in tomato peels from the Bulgarian cultivar "Stela" are $\beta$-carotene (293.4 mg/100 g), lycopene (167.9 mg/100 g), and lutein (13.58 mg/100 g). 
Series of experiments were carried out with varying enzyme concentrations in order to establish the influence of enzymatic treatment on the carotenoid extraction yield. The results are presented in Table 1.

Table 1. Influence of enzyme concentration on carotenoid extraction from tomato peels

\begin{tabular}{|c|c|c|c|c|}
\hline Enzyme & $\begin{array}{c}\text { Enzyme } \\
\text { concentration } \\
\left(\mathrm{Ug}^{-1}\right)\end{array}$ & $\begin{array}{l}\beta \text {-Carotene } \\
(\mathrm{mg} / 100 \mathrm{~g})\end{array}$ & $\begin{array}{l}\text { Lycopene } \\
(\mathrm{mg} / 100 \mathrm{~g})\end{array}$ & $\begin{array}{l}\text { Total carotenoids } \\
\quad(\mathrm{mg} / 100 \mathrm{~g})\end{array}$ \\
\hline $\begin{array}{l}\text { Pectinase } \\
\left(1 \mathrm{~h}, \mathrm{pH} 5.0,20{ }^{\circ} \mathrm{C}\right)\end{array}$ & $\begin{array}{l}100 \\
150 \\
200 \\
250 \\
300 \\
500\end{array}$ & $\begin{array}{l}(16.90 \pm 0.48)^{\mathrm{a}} \\
(18.43 \pm 0.48)^{\mathrm{b}} \\
(20.68 \pm 0.48)^{\mathrm{c}} \\
(23.75 \pm 0.48)^{\mathrm{d}} \\
(22.17 \pm 0.48)^{\mathrm{d}} \\
(22.90 \pm 0.48)^{\mathrm{cd}}\end{array}$ & $\begin{array}{l}(7.38 \pm 0.08)^{\mathrm{a}} \\
(7.77 \pm 0.81)^{\mathrm{b}} \\
(8.97 \pm 1.22)^{\mathrm{ac}} \\
(11.92 \pm 0.81)^{\mathrm{d}} \\
(11.89 \pm 0.84)^{\mathrm{d}} \\
(11.17 \pm 0.18)^{\mathrm{d}}\end{array}$ & $\begin{array}{l}(26.10 \pm 0.59)^{\mathrm{a}} \\
(29.26 \pm 1.49)^{\mathrm{b}} \\
(31.37 \pm 0.30)^{\mathrm{c}} \\
(37.60 \pm 0.44)^{\mathrm{d}} \\
(34.63 \pm 3.43)^{\mathrm{d}} \\
(36.63 \pm 0.60)^{\mathrm{d}}\end{array}$ \\
\hline $\begin{array}{l}\text { Endo-xylanase } \\
\left(1 \mathrm{~h}, \mathrm{pH} 5.0,20^{\circ} \mathrm{C}\right)\end{array}$ & $\begin{array}{l}100 \\
200 \\
300 \\
400 \\
500 \\
600\end{array}$ & $\begin{array}{l}(21.67 \pm 0.00)^{\mathrm{a}} \\
(21.82 \pm 0.00)^{\mathrm{a}} \\
(22.78 \pm 0.21)^{\mathrm{b}} \\
(24.13 \pm 0.48)^{\mathrm{c}} \\
(24.12 \pm 0.07)^{\mathrm{c}} \\
(24.47 \pm 0.38)^{\mathrm{c}}\end{array}$ & $\begin{array}{l}(8.87 \pm 0.00)^{\mathrm{a}} \\
(9.89 \pm 0.00)^{\mathrm{b}} \\
(11.46 \pm 0.52)^{\mathrm{c}} \\
(15.41 \pm 0.06)^{\mathrm{d}} \\
(14.67 \pm 0.01)^{\mathrm{e}} \\
(12.30 \pm 0.18)^{\mathrm{f}}\end{array}$ & $\begin{array}{l}(32.84 \pm 0.00)^{\mathrm{a}} \\
(34.10 \pm 0.00)^{\mathrm{b}} \\
(36.78 \pm 0.80)^{\mathrm{c}} \\
(42.52 \pm 0.59)^{\mathrm{d}} \\
(41.67 \pm 0.08)^{\mathrm{d}} \\
(39.71 \pm 0.55)^{\mathrm{e}}\end{array}$ \\
\hline $\begin{array}{l}\text { Cellulase } \\
\left(1 \mathrm{~h}, \mathrm{pH} 5.0,20^{\circ} \mathrm{C}\right)\end{array}$ & $\begin{array}{c}50 \\
100 \\
110 \\
120\end{array}$ & $\begin{array}{l}(19.53 \pm 0.22)^{\mathrm{a}} \\
(24.40 \pm 0.85)^{\mathrm{b}} \\
(23.94 \pm 0.57)^{\mathrm{b}} \\
(23.53 \pm 0.01)^{\mathrm{b}}\end{array}$ & $\begin{array}{l}(10.15 \pm 0.09)^{\mathrm{a}} \\
(13.58 \pm 0.25)^{\mathrm{b}} \\
(12.36 \pm 0.16)^{\mathrm{c}} \\
(12.69 \pm 0.80)^{\mathrm{bc}}\end{array}$ & $\begin{array}{l}(32.21 \pm 0.30)^{\mathrm{a}} \\
(40.84 \pm 1.19)^{\mathrm{b}} \\
(39.57 \pm 0.01)^{\mathrm{b}} \\
(38.99 \pm 0.81)^{\mathrm{b}}\end{array}$ \\
\hline $\begin{array}{l}\text { Proteinase } \\
\left(1 \mathrm{~h}, \mathrm{pH} 8.0,20^{\circ} \mathrm{C}\right)\end{array}$ & $\begin{array}{c}50 \\
100 \\
200 \\
300\end{array}$ & $\begin{array}{l}(20.38 \pm 0.35)^{\mathrm{a}} \\
(23.52 \pm 0.50)^{\mathrm{b}} \\
(20.66 \pm 0.31)^{\mathrm{a}} \\
(21.09 \pm 0.67)^{\mathrm{a}}\end{array}$ & $\begin{array}{c}(10.07 \pm 0.25)^{\mathrm{a}} \\
(11.34 \pm 0.04)^{\mathrm{b}} \\
(10.62 \pm 0.18)^{\mathrm{ab}} \\
(10.04 \pm 0.27)^{\mathrm{ab}}\end{array}$ & $\begin{array}{l}(32.73 \pm 0.75)^{\mathrm{a}} \\
(37.47 \pm 0.52)^{\mathrm{b}} \\
(33.79 \pm 0.15)^{\mathrm{a}} \\
(33.47 \pm 0.30)^{\mathrm{a}}\end{array}$ \\
\hline
\end{tabular}

The data are means \pm standard deviation of three independent replicates.

$\mathrm{a}-\mathrm{f}$ : The values with different letters in the column indicate significant differences $(\mathrm{P}<0.05)$.

Maximum carotenoid yields were obtained when the following enzyme concentrations were used: pectinase: $250 \mathrm{U} \mathrm{g} \mathrm{g}^{-1}$; cellulose: $100 \mathrm{U} \mathrm{g}^{-1}$; endo-xylanase: $400 \mathrm{U} \mathrm{g} \mathrm{g}^{-1}$, and proteinase: $100 \mathrm{U} \mathrm{g}^{-1}$. The enzymatic treatment with endo-xylanase had the greatest effect producing the highest carotenoid yield.

The results on the kinetics of the enzymatic treatment of the raw material with the optimum enzyme concentrations at a constant temperature of $20^{\circ} \mathrm{C}$ and optimum $\mathrm{pH}$ are presented in Table 2 .

The statistical processing of the data showed that the maximum lycopene and total carotenoid yields were obtained after three-hour treatment with pectinase and four-hour treatment with the other three tested enzymes. There were no statistical differences between the $\beta$-carotene yields obtained after 1 and $5 \mathrm{~h}$ of enzymatic treatment $(\mathrm{P}>0.05)$. It was also reported that the optimum time for enzymatic treatment of tomato peels with cellulase and pectinase at optimum enzyme concentrations and temperature of $20{ }^{\circ} \mathrm{C}$ was $4 \mathrm{~h}$; after that, oxidative processes occurred and the carotenoid yield decreased (RANVEER et al., 2013). 
Table 2. Influence of the enzymatic treatment time on carotenoid extraction from tomato peels

\begin{tabular}{|c|c|c|c|c|c|}
\hline \multirow[t]{3}{*}{ Enzyme } & \multicolumn{5}{|c|}{ Treatment time $(\mathrm{h})$} \\
\hline & 1.0 & 2.0 & 3.0 & 4.0 & 5.0 \\
\hline & \multicolumn{4}{|c|}{$\beta$-Carotene $(\mathrm{mg} / 100 \mathrm{~g})$} & \\
\hline Pectinase & $(23.86 \pm 1.00)^{\mathrm{a}}$ & $(23.61 \pm 0.04)^{\mathrm{a}}$ & $(24.58 \pm 0.76)^{\mathrm{a}}$ & $(24.34 \pm 1.11)^{\mathrm{a}}$ & $(24.05 \pm 0.13)^{\mathrm{a}}$ \\
\hline Cellulase & $(24.91 \pm 0.05)^{\mathrm{a}}$ & $(23.99 \pm 0.07)^{b}$ & $(24.33 \pm 0.41)^{\mathrm{a}}$ & $(24.24 \pm 0.34)^{b}$ & $(25.22 \pm 0.04)^{\mathrm{a}}$ \\
\hline Endo-xylanase & $(24.35 \pm 0.48)^{\mathrm{a}}$ & $(23.96 \pm 0.13)^{\mathrm{a}}$ & $(23.90 \pm 0.05)^{\mathrm{a}}$ & $(23.51 \pm 0.04)^{\mathrm{a}}$ & $(23.88 \pm 0.08)^{\mathrm{a}}$ \\
\hline Proteinase & $(23.07 \pm 0.13)^{\mathrm{a}}$ & $(22.26 \pm 0.14)^{\mathrm{a}}$ & $(22.98 \pm 0.09)^{\mathrm{a}}$ & $(23.15 \pm 0.06)^{\mathrm{a}}$ & $(23.42 \pm 0.19)^{\mathrm{a}}$ \\
\hline \multicolumn{6}{|c|}{ Lycopene $(\mathrm{mg} / 100 \mathrm{~g})$} \\
\hline Pectinase & $(11.20 \pm 0.14)^{\mathrm{a}}$ & $(12.32 \pm 0.09)^{\mathrm{b}}$ & $(13.20 \pm 0.48)^{\mathrm{c}}$ & $(13.06 \pm 0.28)^{\mathrm{c}}$ & $(12.43 \pm 0.06)^{b}$ \\
\hline Cellulase & $(11.80 \pm 0.09)^{\mathrm{a}}$ & $(13.50 \pm 0.06)^{b}$ & $(14.03 \pm 0.70)^{b}$ & $(15.31 \pm 0.21)^{\mathrm{c}}$ & $(13.86 \pm 0.04)^{\mathrm{b}}$ \\
\hline Endo-xylanase & $(12.12 \pm 0.16)^{\mathrm{a}}$ & $(13.51 \pm 0.04)^{b}$ & $(14.32 \pm 0.17)^{\mathrm{c}}$ & $(15.18 \pm 0.09)^{\mathrm{d}}$ & $(11.74 \pm 0.18)^{\mathrm{e}}$ \\
\hline Proteinase & $(11.20 \pm 0.14)^{\mathrm{a}}$ & $(12.76 \pm 0.15)^{b}$ & $(12.75 \pm 0.31)^{\mathrm{b}}$ & $(13.82 \pm 0.25)^{\mathrm{c}}$ & $(13.10 \pm 0.21)^{b}$ \\
\hline \multicolumn{6}{|c|}{ Total carotenoid $(\mathrm{mg} / 100 \mathrm{~g})$} \\
\hline Pectinase & $(37.00 \pm 0.06)^{\mathrm{a}}$ & $(38.64 \pm 0.13)^{b}$ & $(40.63 \pm 0.30)^{\mathrm{c}}$ & $(40.21 \pm 0.90)^{\mathrm{c}}$ & $(39.48 \pm 0.14)^{b}$ \\
\hline Cellulase & $(39.47 \pm 0.16)^{\mathrm{a}}$ & $(40.41 \pm 0.02)^{b}$ & $(40.76 \pm 0.49)^{b}$ & $(42.52 \pm 0.60)^{\mathrm{c}}$ & $(41.99 \pm 0.15)^{\mathrm{c}}$ \\
\hline Endo-xylanase & $(40.55 \pm 0.78)^{\mathrm{a}}$ & $(40.39 \pm 0.04)^{\mathrm{a}}$ & $(41.23 \pm 0.05)^{\mathrm{a}}$ & $(41.60 \pm 0.11)^{b}$ & $(39.41 \pm 0.24)^{\mathrm{c}}$ \\
\hline Proteinase & $(36.82 \pm 0.33)^{\mathrm{a}}$ & $(37.87 \pm 0.04)^{b}$ & $(38.59 \pm 0.20)^{\mathrm{c}}$ & $(39.82 \pm 0.24)^{\mathrm{d}}$ & $(39.45 \pm 0.19)^{d}$ \\
\hline
\end{tabular}

Enzymatic treatment was applied at $20^{\circ} \mathrm{C}$ and $\mathrm{pH} 5.0$ for pectinase, cellulase, and endo-xylanase and $\mathrm{pH} 8.0$ for proteinase.

The data are means \pm standard deviation of three independent replicates.

a-e: values with different letters indicate significant differences $(\mathrm{P}<0.05)$

Data on the effect of enzymatic treatment at the above-stated optimum enzyme concentrations, processing time of $4 \mathrm{~h}$, constant temperature of $20{ }^{\circ} \mathrm{C}$, and optimum $\mathrm{pH}$ on the $\beta$-carotene, lycopene, and total carotenoid yields, are presented in Figures 1, 2, and 3.

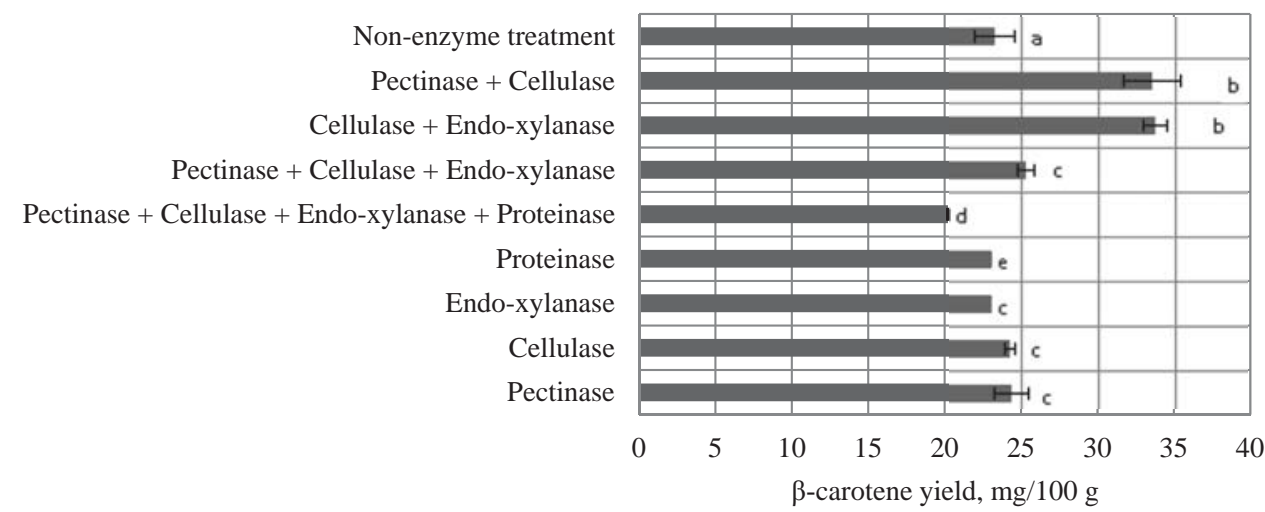

Fig. 1. Effect of enzymatic treatment on $\beta$-carotene extraction from tomato peels. Enzymatic pretreatment for $4 \mathrm{~h}$ at $20^{\circ} \mathrm{C}$ followed by acetone extraction for $30 \mathrm{~min}$ at $20^{\circ} \mathrm{C}$ and solid/liquid ratio of $1: 30$. (The data are means \pm standard deviation of three independent replicates. Different letters indicate significant differences $\mathrm{P}<0.05$ ) 


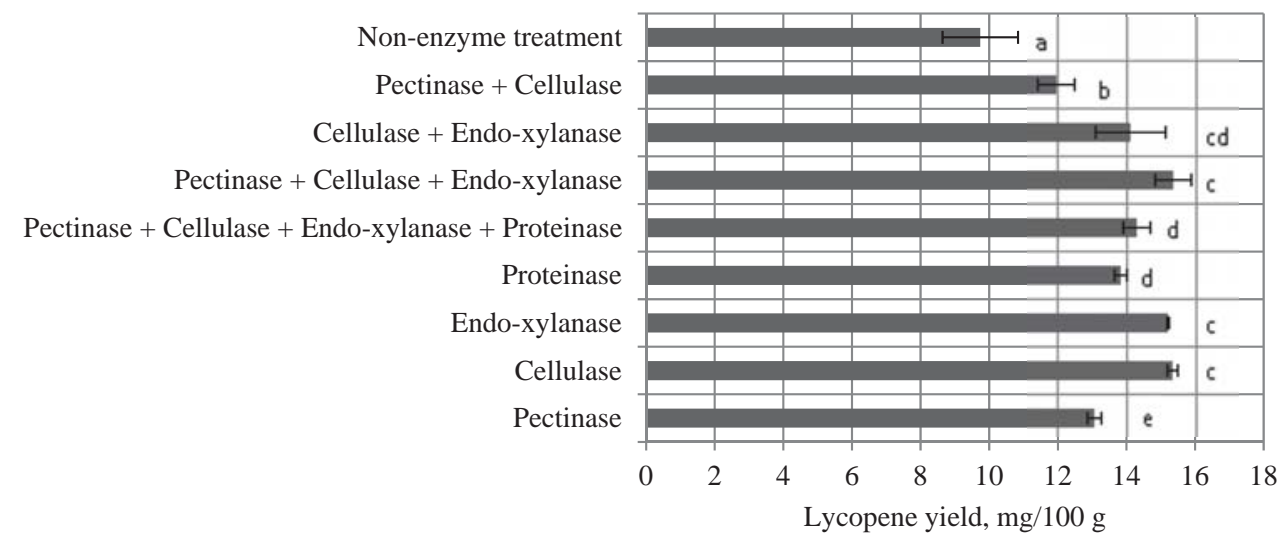

Fig. 2. Effect of enzymatic treatment on lycopene extraction from tomato peels. Enzymatic pretreatment for $4 \mathrm{~h}$ at $20^{\circ} \mathrm{C}$ followed by acetone extraction for $30 \mathrm{~min}$ at $20^{\circ} \mathrm{C}$ and solid/liquid ratio of $1: 30$. (The data are means \pm standard deviation of three independent replicates. Different letters indicate significant differences $\mathrm{P}<0.05$ )

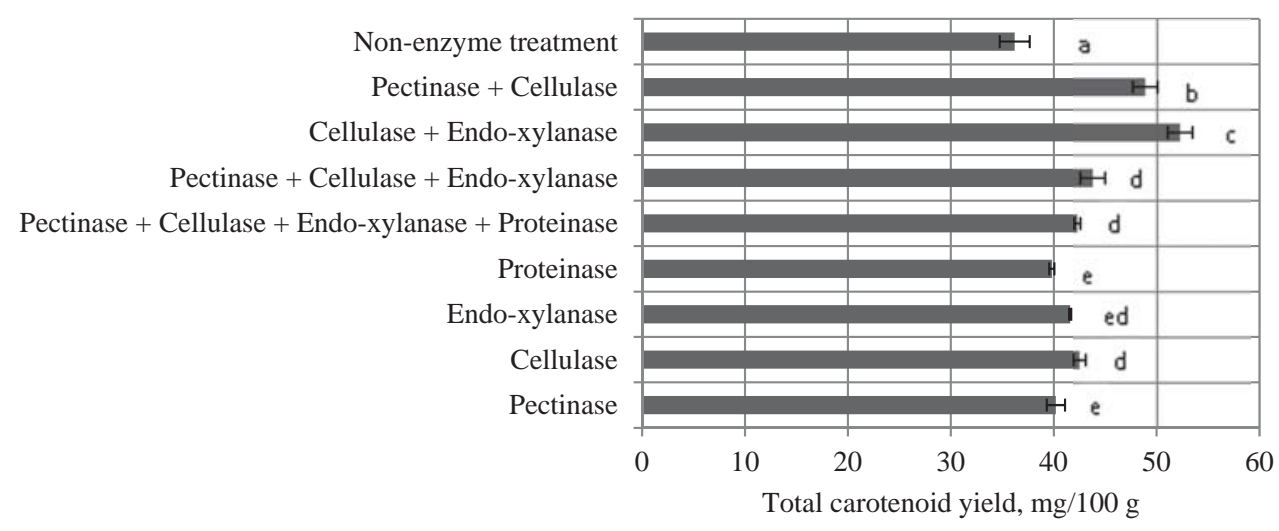

Fig. 3. Effect of enzymatic treatment on total carotenoid extraction from tomato peels. Enzymatic pretreatment for $4 \mathrm{~h}$ at $20^{\circ} \mathrm{C}$ followed by acetone extraction for $30 \mathrm{~min}$ at $20^{\circ} \mathrm{C}$ and solid/liquid ratio of 1:30. (The data are means \pm standard deviation of three independent replicates. Different letters indicate significant differences $\mathrm{P}<0.05$ )

The results indicated that the enzyme-assisted extraction of carotenoids led to an increased yield compared to the control sample. The maximum yields of $\beta$-carotene $(33.67 \pm 0.77 \mathrm{mg} / 100 \mathrm{~g})$ and total carotenoid $(52.20 \pm 1.19 \mathrm{mg} / 100 \mathrm{~g})$ were obtained by combined treatment with cellulase and endo-xylanase (Figs 1 and 3). The highest lycopene yield $(15.33 \pm 0.73 \mathrm{mg} / 100 \mathrm{~g})$ was produced by an enzyme combination of pectinase, cellulase, and endo-xylanase (Fig. 2). These results were probably due to the synergistic action of enzymes. However, the statistical processing of the data showed no significant differences $(\mathrm{P}>0.05)$ between the lycopene extraction yields after treatment with enzyme combinations of pectinase, cellulase, endo-xylanase, and cellulase plus endo-xylanase. Therefore, it can be assumed with a sufficient level of confidence that the greatest effect on the carotenoid yield was achieved by processing the raw material with an enzyme combination of cellulase and 
endo-xylanase. An increase in the extraction yields by 1.5, 1.4, and 1.4 times, respectively, for lycopene, $\beta$-carotene, and total carotenoid extraction after combined treatment with cellulase and endo-xylanase in comparison with the non-enzymatic treatment of tomato peels was established. In other studies, it was also found that there was an increase of 1.5 to 20 times in the lycopene yield from tomato waste as a result of enzymatic treatment with pure enzymes and various commercial enzyme preparations at different conditions (CHOUDHARI \& AnANthanarayan, 2007; Zuorro et al., 2011).

Another important factor that affects enzymatic treatment is temperature. Therefore, combined enzymatic pretreatment with cellulase and endo-xylanase at $20{ }^{\circ} \mathrm{C}$ and $50{ }^{\circ} \mathrm{C}$ was carried out for $4 \mathrm{~h}$. The results are presented in Figure 4.

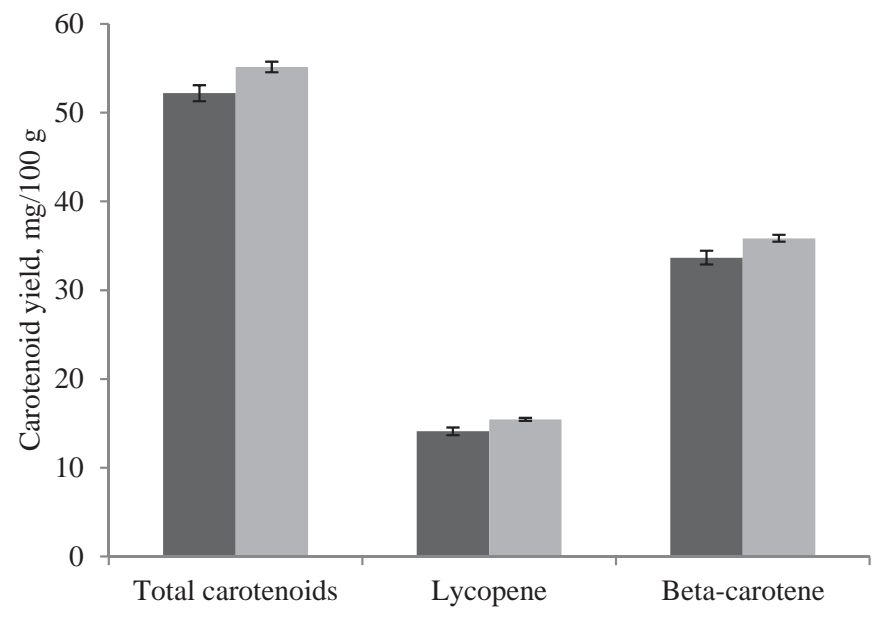

Fig. 4. Effect of enzymatic treatment temperature on carotenoid extraction from tomato peels. (The data are means \pm standard deviation of three independent replicates) ㄷ: $20^{\circ} \mathrm{C}$; $\square: 50{ }^{\circ} \mathrm{C}$

An increase in the enzymatic treatment temperature from $20{ }^{\circ} \mathrm{C}$ to $50{ }^{\circ} \mathrm{C}$ led to $10 \%$, $7 \%$, and $6 \%$ increase in the lycopene, $\beta$-carotene, and total carotenoid yields, respectively. The enzyme-assisted extraction of carotenoids using mixed cellulase and endo-xylanase enzymes for $4 \mathrm{~h}$ at $50{ }^{\circ} \mathrm{C}$ led to $58.5 \%, 54.2 \%$, and $52.3 \%$ increase in the lycopene, $\beta$-carotene, and total carotenoid yields, respectively, compared to the non-enzyme treatment.

\section{Conclusions}

Considerable amounts of tomato by-products are produced in the world and discharged as solid waste. As a result, the utilization of this material as a low-cost source of carotenoids provides both economic and environmental benefits. The results of this study indicated that the pretreatment of tomato peels with mixed cellulolytic and hemi-cellulolytic enzymes was a good approach for carotenoid recovery. In particular, the pretreatment of Bulgarian tomato peels with a mixture of cellulase $\left(100 \mathrm{U} \mathrm{g} \mathrm{g}^{-1}\right)$ and endo-xylanase $\left(400 \mathrm{U} \mathrm{g}^{-1}\right)$ for $4 \mathrm{~h}$ at $50{ }^{\circ} \mathrm{C}$ resulted in up to 1.6-fold increase in the carotenoid extraction yield. 


\section{References}

Choudhari, S.M. \& Ananthanarayan, L. (2007): Enzyme aided extraction of lycopene from tomato tissues. Food Chem., 102, 77-81.

Cuccolini, S., Aldini, A., Visai, L., Daglia, M. \& Ferrari, D. (2013): Environmentally friendly lycopene purification from tomato peel waste: Enzymatic assisted aqueous extraction. J. Agr. Food Chem., 61, 1646-1651.

González, I., Valverde, V., Alonso, J. \& Periago, M. (2011): Chemical profile, functional and antioxidant properties of tomato peel fibre. Food Res. Int., 44, 1528-1535.

Hdider, C., Ilahy, R., Tlili, I., Lenucci, M. \& Dalessandro, G. (2013): Effect of the stage of maturity on the antioxidant content and antioxidant activity of high-pigment tomato cultivars grown in Italy. Food, Global Science Books, 7 (Special Issue 1), 1-7.

Ilahy, R., Piro, G., Tlili, I., Riahi, A., Sihem, R., Onerghi, I., Hdider, C. \& Lenucci, M. (2016): Fractionate analysis of the phytochemical composition and antioxidant activities in advanced breeding lines of high-lycopene tomatoes. Food Funct., 7, 574-583.

Konwarh, R., Pramanik, S., Kalita, D., Mahanta, C. \& Karak, N. (2012): Ultrasonication - a complementary "green chemistry" tool to biocatalysis: A laboratory-scale study of lycopene extraction. Ultrason. Sonochem., 19, 292-299.

Lenucci, M., Caccioppola, A., Durante, M., Serrone, L., Honardo, R. \& Piro, G. (2010): Optimization of biological and physical parameters for lycopene supercritical $\mathrm{CO}_{2}$ extraction from ordinary and high-pigment tomato cultivars. J. Sci. Food Agr., 90, 1709-1718.

Lenucci, M., Caroli, M., Marrese, P., Iurlaro, A., Rescoi, L., Böhm, V., Dalessandro, G. \& Piro, G. (2015): Enzyme-aided extraction of lycopene from high-pigment tomato cultivars by supercritical carbon dioxide. Food Chem., 170, 193-202.

Manuelyan, H. (1991): Express methods for assessing the carotenoid composition of tomato fruits. -in: Kallo, G. (Ed.) Genetic improvement of tomato. Springer-Verlag, pp. 193-195.

Nikolova, M., Prokopov, T., Ganeva, D. \& Pevicharova, G. (2014): Effect of treatment parameters on the carotenoid extraction from tomato peels of Bulgarian industrial varieties. Food Environ. Safety, 13(4), 283-289.

Papaiofnnou, E. \& Karabelas, A. (2012): Lycopene recovery from tomato peel under mild conditions assisted by enzymatic pre-treatment and non-ionic surfactants. Acta Biochim. Pol., 59(1), 71-74.

RanVeER, R., PAtil, S. \& SAHOO, A. (2013): Effect of different parameters on enzyme-assisted extraction of lycopene from tomato processing waste. Food Bioprod. Process., 91, 370-375.

Simkin, A., Gaffe, J., Alcaraz, J-P., Carde, J-P., Bramley, P., Fraser, P. \& Kuntz, M. (2007): Fibrillin influence on plastid ultrastructure and pigment content in tomato fruit. Phytochemistry, 68, 1545-1556.

Sowbhagya, H. \& Chita, V. (2010): Enzyme-assisted extraction of flavorings and colorants from plant materials. Crit. Rev. Food Sci. Nutr., 50, 146-161.

Strati, I., Gogou, E. \& Oreopoulou, V. (2015): Enzyme and high pressure assisted extraction of carotenoids from tomato waste. Food Bioprod. Process., 94, 668-674.

Strati, I. \& Oreopoulou, V. (2011): Effect of extraction parameters on the carotenoid recovery from tomato waste. Int. J. Food Sci. Tech., 46, 23-29.

Zuorro, A., Fidaleo, M. \& Lavecchia, R. (2011): Enzyme-assisted extraction of lycopene from tomato processing waste. Enzyme Microb. Tech., 49, 567-573.

Zuorro, A., Lavecchia, R., Medici, F. \& Piga, L. (2013): Enzyme-assisted production of lycopene from tomato processing waste. Food Bioprocess Tech., 6, 3499-3509.

Zuorro, A., Lavecchia, R., Medici, F. \& Piga, L. (2014): Use of cell wall degrading enzymes for the production of high-quality functional products from tomato processing waste. Chem. Engineer. Trans., 38, 355-360. 